\title{
Borders, Labour Impacts, and Union Responses: Case of Spain
}

\author{
LUKe STOBART
}

\section{Abstract}

Spain is an acute example of severe yet permissive border control where institutional frameworks ensure that migrant labour inexpensively fills existing labour shortages and highly exploitative "niches," while aiding a broader flexibilization strategy. Through a review of mainly Spanish research by trade union, industrial relations, and immigration specialists on three major migrant employment sectors, the article shows that impacts on employment and wage levels have been limited, despite claims to the contrary, although they have been deeper in those employment sectors with reduced legal protection and union organization. It concludes that while the Spanish case gives support to the No Borders position, it also exposes the need for greater engagement with migrant workers by the trade unions and rejects the major Spanish union federations' recent advocacy of "controlled immigration."

\section{Résumé}

L'Espagne est un exemple aigu d'un contrôle rigoureux quoique permissif des frontières où les cadres institutionnels font en sorte que les travailleurs migrants comblent à peu de frais les pénuries de main-d'ouvre existantes et les créneaux susceptibles d'une forte exploitation, tout en facilitant une stratégie de d'assouplissement étendue. À travers un examen de la recherche principalement espagnole sur les trois principaux secteurs de l'emploi des migrants par des experts en syndicalisme, relations industrielles et immigration, l'auteur montre qu'en dépit d'affirmations a contrario les effets sur les niveaux d'emploi et les salaires ont été limités, bien qu'ils se soient fait sentir plus profondément dans les secteurs de l'emploi où la protection juridique et l'organisation syndicale demeurent insuffisantes. En guise de conclusion, l'auteur soutient que si le cas de
l'Espagne conforte la position du mouvement No Border, il fait néanmoins ressortir la nécessité d'un plus grand engagement auprès des travailleurs migrants de la part des syndicats et va à l'encontre du plaidoyer récent des grandes fédérations syndicales espagnoles en faveur de «l'immigration contrôlée».

\section{Introduction}

In this article I will attempt to add to the debate on the validity of the No Borders thesis by analyzing a polemical area among progressive analysts: the impact of controlled migration on labour conditions-of both migrant and non-migrant workers. ${ }^{1}$ My contribution will take the form of a national case study, that of the Spanish State, ${ }^{2}$ in which a combination of strictness and permissiveness in border control has combined with specific legislative constraints to shape the labour and self-organization of migrants, inserted into an unfavourable context of extensive informal employment and precarious labour relations. This, as we shall explore, has been a factor contributing to growing anti-immigrant attitudes in Spanish society and even large-scale racist attacks. In response, a significant level of debate has emerged within the trade unions and the mainstream and radical left about the effects of migration on the poorer classes.

My method shall be to contextualize the subject within the actuality of migrant employment and policy and then critically interpret several recent Spanish studies dealing with impacts on pay and employment. These include a study on the trade unions and migration, "Los sindicatos ante la inmigración," directed by Carmen González-Enríquez for the government-attached Observatorio Permanente de la Inmigración (Permanent Observatory of Immigration, OPI) which concludes with a negative assessment of the effect of migrants on the employment and conditions of non-migrants and supports the two main union federations' current defence of "controlled immigration." I also explore 
research by Miguel Pajares, the ex-coordinator for migrant services (CITE) at the Catalan Comisiones Obreras (CCOO) federation, which, in contrast, identified a negligible negative effect. ${ }^{4}$

In accord with Pajares, I shall demonstrate, through interpretation of the range of sources, that the negative effects associated with migrant employment are exaggerated; and that controls, rather than benefiting the socio-economic conditions of working people, allow for the super-exploitation of migrant labour and facilitate the undercutting of labour as a whole. I end by reaffirming that migrant labour is itself a key subject in determining labour outcomes, and advocating locating the organization of migrant labour at the centre of trade-union strategies.

\section{Migrant Labour in Spain}

Large-scale immigration into Spain is a relatively new phenomenon (at least under capitalism). In a similar way to other Mediterranean countries (and Ireland), Spain was until recently a net source of migration-with large numbers of people emigrating to northern Europe and other regions. In 1996 , of the total population only 1.5 per cent $(600,000$ persons) were foreign-born, of which half were from other European countries. Linked to Spain's relatively substantial economic growth (of 4.1 per cent annually between 1996 and 2000; and 3.1 per cent from 2001 to 2005), ${ }^{5}$ the foreign population has increased markedly to currently represent around 12 per cent of the total Spanish population. Within the Spanish workforce, migrant workers represent 14.3 per cent ( 2.9 million) of the total. ${ }^{6}$ This is a relatively quick and pronounced transformation for an economically developed country by today's standards.

A large number of foreign residents in Spain are EU citizens (between a third and a half of the total foreign population in $2005^{7}$ ), of which a significant group are relatively wealthy, often retired citizens from northern Europe-in 2005 British and German citizens were numerically the fifth and seventh largest foreign collectives in Spain. ${ }^{8}$ These immigrants are normally not treated as such in discussions on the topic in Spain, although their numbers are included in media and academic studies on the extension of migration and migrant labour in Spain. In this study I shall follow standard Spanish practice and not refer to western Europeans when I refer to "migrants" or "immigrants," although I am conscious that this creates definitional issues, for example a possible reinforcing of perceptions of migrants as "low wage" and "low skilled." When I use figures that include Europeans, I shall refer to the population in question as "foreign."

Despite the continued arrival of these more affluent groups on Spanish territory, Spain's foreign population has diversified to progressively integrate more migrants from the "Global South" and Eastern Europe. Consequently, in 2005 , the first four largest groups of resident non-Spaniards were, in order of size, Moroccans (505,400 persons), Ecuadorians (491,800), Romanians (314,300), and Colombians $(268,900 .)^{9}$

Before the current crisis, which has been especially severe in the Spanish case, migration into Spain was frequently presented as an economic success story in both international and Spanish political, business, and media circles. Several studies have shown migrant labour to have been fundamental to Spain's economic expansion. Spanish GDP per capita increased by 2.6 per cent between 1995 and 2005, and an investigation by the Caixa de Catalunya bank found that without migration, GDP per capita would have contracted by -1.17 per cent. The economic office of Spanish president Luís Rodríguez Zapatero has estimated that migrant workers (and their contributions to the socialsecurity system) had produced as much as 51.6 per cent of economic growth from 2001 to $2005 .^{10}$ These are dramatic figures by any standards.

Nevertheless Spanish economic strategy had centred on traditional low-capital-investment sectors (such as construction, agriculture, and tourism), in which migrant labour has played a significant role. Since the collapse in 2008 of an enormous housing bubble, which coincided with the international banking crisis, these sectors have encountered serious difficulties and have shed large numbers of jobs. This is especially so in the construction sector. One consequence has been that migrant unemployment rose by 64 per cent in the year before the last quarter of $2008 .{ }^{11} \mathrm{~A}$ year later (in mid-2009) 28 per cent of all "foreigners" were unemployed-a notably higher figure than for "natives" (16 per cent). ${ }^{12}$

Even prior to the downturn the migrant population was in a precarious socio-economic position. Most of its members arrived shortly after a successful drive (initiated by the social-democratic PSOE government of Felipe González in the late 1980s and early 1990s) to "flexibilize" large sections of the workforce, as a result of which Spain is among the countries with the highest proportion of "temporary" employment among the states included in the Organisation for Economic Cooperation and Development (OECD). It is also a country with a large (and officially tolerated) underground economy which is estimated as accounting for 25 per cent of Spain's Gross National Product (GNP). ${ }^{13}$ It is into the above employment context that migrant labour has been incorporated.

Real differences that exist between the migrant workforce and the Spanish-born workforce have been exploited by politicians taking a populist stance (in particular those from 
the right-wing Popular Party, or PP) and sections of the media. This has encouraged a negative sentiment towards immigration in Spanish society. In recent years, monthly surveys on public opinion by the sociological research body, the Centro de Investigaciones Sociológicas (CIS), have frequently identified "immigration" to be one of the biggest national "problems." At times, such as in September 2006 when a sizable number of undocumented migrants arrived by boat in the Canary Islands, it figured as the number one problem by 60 per cent of those interviewed. ${ }^{14}$

There have also been cases of substantial racist violence in different points of the peninsula. The worst example was a local pogrom against North African migrants which occurred on 6 February 2000 in the Andalusian agricultural town of El Ejido. In this, 374 immigrants reported being physically attacked and 221 losing their homes, making the incident the most serious of its kind in Europe for decades. ${ }^{15}$

The subsequent media and academic attention given to the event unearthed the conditions in which a large number of migrants were working and living in Spain. In the area near El Ejido, 9,000 farms had adopted an economically successful method of farming horticultural products in high-temperature plastic greenhouses, in an area among the hottest in Europe ${ }^{16}$ Seventy per cent of the migrant workforce employed in the installations proved to be undocumented..$^{17}$ Fixed-term contracts and low wages were the norm. ${ }^{18}$ Migrants were discovered to be living away from the town in shacks or amongst ruins, lacking basic amenities such as water and public transport. ${ }^{19}$ The flip side was that the business model was extremely lucrative for the local native farmers, and the region transformed from one of the poorest per capita in Europe to one of the richest. ${ }^{20}$

It was also highly segregated and the local mayor (PP) made clear that he backed this, stating, "Immigrants are good for the municipality while they are working, but they must take the bus and leave at seven in the evening." 21 In a context of "apartheid-style" inequality, segregation, and attitudes, ${ }^{22}$ a killing of a local woman by a mentally unstable Moroccan sparked the violence described. ${ }^{23}$

There were two interesting and, it could be argued, related responses to the events that are relevant to the present discussion. Firstly, local migrant workers reacted by holding a general strike, occurring in the middle of harvesting and eventually costing the employers millions of euros. After eight days of strike action, negotiations between unions, NGOs, political authorities, and farmers' associations agreed to provide emergency housing, public transport, and compensation for damages, as well as improving wages and conditions. This was initially an example of successful union mobilization by migrants and it encouraged further strikes by immigrant agricultural workers, including in
Catalonia. However the North Africans received threats (as did NGOs that had defended them), and were openly discriminated against in employment. As a result, almost all abandoned the region, ${ }^{24}$ and the agreements reached were not implemented.

The other significant event in relation to the conflict was that in the following months the PP government passed a new Aliens Law (Ley de Extranjería), which, among other restrictive measures, removed the right of irregular migrants to hold meetings, join "associations" (including unions), demonstrate, or strike. There was much public discussion about whether this was "unconstitutional," and a left-wing Catalan nationalist suggested in Congress that it would turn all migrants into "cheap labour." 25 A supporter of the new law, the president of the governmental Forum for the Social Integration of Immigrants, Mikel Azurmendi, who led an investigation into the El Ejido violence, ${ }^{26}$ would later say of the previous law, "With the right to assemble, demonstrate and strike in their hands, [ ... ] that immigrant mass [ ... ] in [Almería and the Canaries] would be a grave factor in social destabilisation and serious conflicts." 27 This can be interpreted as an extreme and transparent advocacy of employing migrants without rights, which in the context of the abuses uncovered in El Ejido has serious implications.

\section{Government Policy and Application}

The political responses to El Ejido outlined imply at least that high levels of exploitation of migrant labour have been tolerated and encouraged by legislation. ${ }^{28}$ There is other evidence that reinforces this proposition, relating to the role of borders in shaping employment patterns. Before attempting an analysis of this, it is useful to describe the situation on Spain's border.

Spain's southern border with Africa has been the site of many tragedies in recent years. As surveillance and patrols (by both Spain and the EU) have been reinforced around the western Mediterranean, and "migratory control" bilateral agreements have been reached between Spain/the EU and nearby North African countries, migrants have been travelling in flimsy boats from as far away as Senegal-over 1,000 kilometres away. The result has been a multiplication of the number of deaths, particularly in the Atlantic Ocean around the Canary Islands, where 6,000 people died in 2006, according to the Canarian regional government. ${ }^{29}$ There also have been more dramatic cases of migrants being shot dead by security forces while trying to cross the high fences surrounding the Spanish North-African enclaves of Ceuta and Melilla, and the Spanish State has received criticisms for having a restrictive asylum policy: out of 2,504 requests for asylum in the first six months of 2006 , the state rejected 
or declared inadmissible 2,165, an acceptance rate of only 13.5 per cent. ${ }^{30}$

The described events might suggest that the Spanish State has a "tough" border policy, which both conservative and Socialist governments have repeatedly claimed is the case. Nonetheless, large numbers of undocumented migrants have continued to enter the country, and even since an extensive regularization process in 2005, the minister for immigration and labour, Celestino Corbacho, has acknowledged the existence of 700,000 irregular workers in the country (a figure which the PP opposition raises to 1.6 million). ${ }^{31}$ Even the government's lower figures show a large pool of undocumented migrants for a country with a population of approximately 45 million. Furthermore, there are signs that many are long-term: one CIS study discovered that 42 per cent of all "irregulares" had resided in Spain for six to ten years. ${ }^{32}$

Clearly Spain's borders are permeable, and local police authorities have even affirmed that they have only symbolic impact. ${ }^{33}$ There are also indications that this widespread irregularity is not merely due to the difficulty of sealing a country's borders in today's globalized world. As well as large numbers of Latin Americans entering Spain with tourist or study visas (which has converted Latinos into the largest sub-group of migrant residents), ${ }^{34}$ a great many foreign residents in Spain do end up entering the peninsula after being apprehended on Spain's southern border. After detention, a minority are repatriated (or sent to a third country), and a larger number sent to internment centres, from where they are released after forty days. Most are then taken to and released in mainland cities. In these cases, they remain under an unenforced expulsion order, which means that in the best of cases they cannot legalize their stay in the country for three years. ${ }^{35}$ Consequently they do not enjoy the legal protections that exist for legally resident citizens.

A study by Wayne Cornelius found that the legal quotas for hiring migrant labour outside Spain fell "far short" of demand; and that the "dysfunctional system of interlinked work to residential permits turns once legal workers into irregulares with dismaying regularity." 36 He says this "limits [many migrant workers'] options to the underground economy or to formal-sector firms that employ them 'off the books," and that the system "has been a great boon to employers: it has helped to institutionalize a system of short term hiring that gives them maximum flexibility to shed labor when it is not needed." 37 A further factor encouraging the illegalization of migrant labour is the Spanish State's refugee policy: as well as being highly restrictive, it allows unsuccessful applicants three months to regularize their situation by obtaining work and visa permits, and, in the words of Cornelius, "the vast majority [ ... ] simply disappear into the underground economy." 38

Journalist and writer Xavier Rius Sant explains the inconsistency between the strictness and laxity of Spanish (and Italian) policy as a "paradox" caused by the European Union pressing the countries (to police their borders), and the need for each to reverse an acute aging of their population. ${ }^{39}$ Another consideration is whether political gains can be made by parties that appear "strict on immigration" while simultaneously improving the potential for high rates of exploitation for Spanish capital.

An objection that might be made to the analysis made thus far is that there have been six large-scale "regularizations" since 1986, ${ }^{40}$ including a substantial process in 2005 in which 700,000 persons benefited. The question arises as to whether this shows a willingness to avoid illegality. Philip Marfleet maintains otherwise, reminding us that such amnesties tend to become recurrent. This, he infers, is because they encourage continued entry by migrants in the hope that they might benefit from a future round of regularization of status. ${ }^{41}$

There are two other factors that lend support to Marfleet's analysis in the Iberian case. The first is that regularizations have excluded many people- 800,000 from the beginning in the case of 2005, according to one estimate. ${ }^{42}$ Second, regularization made residence permits conditional on having work permits, meaning migrants' legal residence became more dependent on the goodwill of their employer. If we accept that having precarious workers is a desired outcome of government policy, as the previous discussion suggests, this implies that paradoxically amnesties are another example of border control promoting a precarious labour force through illegality.

A final point concerns the enforcement of the laws against illegal hiring. Employers are rarely sanctioned for breaking these. An exceptional case (when a businessman was arrested after the death of twelve undocumented Ecuadorians in a work-related driving accident in Lorca) was followed by 20,000 sackings, mainly of Ecuadorians, in just one region of Spain! ${ }^{43}$ The uniqueness of this example provides further evidence of a silent strategy to supply Spanish business with a large layer of undocumented labour. The result concurs with Saskia Sassen that border controls act to facilitate "the extraction of cheap labour by assigning criminal status to a segment of the working class." 44 They thus act as a "mould" helping create a new type of "Kleenex" (or disposable) worker. ${ }^{45}$

\section{Impacts}

In the years immediately prior to the crisis, employers and most of the media, alongside the governing Spanish Socialist 
Party (PSOE) and smaller progressive and regional parties, have argued the "economic case" for migration. They have been supported in this by the economic studies mentioned above. Most studies maintained that migration had a negligible impact on the availability of employment and had the "positive" effect of increasing flexibility and wage restraint. For example, Guillermo de la Dehesa, of the Centre for Economic Policy Research, says immigrant labour encourages "wage moderation and the flexibilisation of the labour market." 46 This echoes ideas put forward by economic liberals internationally. For example, Alan Greenspan, while chairman of the US Federal Reserve, argued for US immigration policies to be relaxed "for growth to be continued without inflation." 47

Such a backdrop may partly explain why anti-immigrant attitudes have gained greater currency in the Spanish workers' movement and sectors of the left. ${ }^{48}$ Sometimes these are "justified" by comparing migrant labour to that which Karl Marx termed the "reserve army of labour." This workforce, in the words of Albert Recio, acts as a "mechanism to suppress wage demands and discipline the working classes." ${ }^{\text {"49 }}$ A CCOO national report subtitled "Proposals for the Regulation of Migratory Flows" writes, "having an important reserve army 'flexibilises' the job market, thanks to immigrant working people's reduced costs-[socialsecurity] contributions and wages-, greater availability and less-demanding attitude towards legal compliance." 50 Revealingly, almost all of the literature consulted for this paper referred to the Marxian concept.

Below I will carefully examine the validity of these descriptions by comparing them with the situation in the three sectors that have incorporated most (legal) migrant labour. These are (according to official Social Security statistics): construction (376,732 employees), hospitality $(210,801)$, and domestic service $(157,192) .{ }^{51}$ They are also sectors that have received significant research attention facilitating analysis. First, however, I shall make a few general observations.

\section{Employment, "Precariedad," and Wages}

The aforementioned $\mathrm{CCOO}$ report states that the flexibility and cost reduction offered by migrant labour "are important incentives for companies to hire labour of foreign origin, even when there is no shortage of autochthonous labour, which produces undesired substitution processes." 52 A similar idea is implied by the industrial relations analyst Albert Recio, who deduces that "substitution" must be occurring from the coexistence in Spain of continued high unemployment with the period of large-scale migration.

It is true that migrant wages in general are lower than those of autochthonous wage earners. According to the 2002 Wage
Structure Survey male immigrant workers earned between 7.2 per cent and 16.3 per cent less than male non-immigrant workers. ${ }^{53}$ Superficially this suggests that employers would have objective cause to prefer employment of immigrants (although at the same time it poses the question of whether employers are discriminating against migrants when hiring). However, there are several reasons why we should be skeptical towards the substitution thesis.

The first is that the "unemployed" in Spain also include a relatively large number of people that work in "informal employment," which Recio himself describes as having "a long tradition" in the territory. ${ }^{54}$ This means that the real levels of unemployment are likely to be significantly lower than official rate. ${ }^{55}$ Additionally, the widespread application of short-term contracts in the job market encourages workers in general to intersperse employment with collecting unemployment compensation ("el paro"). The above factors have meant that in some provinces it is estimated that 60 to 70 per cent of residents are signing on and not looking for legal employment. ${ }^{56}$

Another weakness with the substitution thesis is that (during the pre-crisis years) the percentage of nationals employed increased faster than the percentage of migrants hired (between 2002 and 2006 up 4.3 per cent in the former case; 3.3 per cent in the case of migrants. $)^{57}$ Carlota Solé explains that the overall pattern "is not about activities being 'vacated' by autochthonous workers but by labour shortages in certain sectors/segments/geographical areas." 58 This conclusion receives support from the fact that two of the sectors that incorporated the most immigrants during the last decade-construction and tourism-were the fastest growing in economic terms. Construction, for example, rose from representing 11.7 per cent to 15.7 per cent of all GDP between 1997 and 2007, ${ }^{59}$ which is an abnormally high percentage and rate of growth. It is difficult to envisage that the corresponding demand for skilled and unskilled labourers in this sector could have been met without large-scale use of migrant labour.

Solé also identified "an important shift upwards" in the "level of acceptance" of job quality by non-migrant labour. ${ }^{60}$ A recent local example would appear to lend support for this interpretation. At the start of the recession, the government contacted 2,034 unemployed Spanish nationals in Huelva to be given precedence for 25,000 local harvesting jobs. Out of those contacted, only 260 attended an interview and 32 accepted the job. ${ }^{61}$

The above reflections contradict any strong substitution thesis, yet they cannot rule out any substitution taking place. There are employment branches that effectively have become "migrant-only," including unpleasant and/ or low-paid work such as live-in domestic service and 
the greenhouse farming already referred to. Some liberals, such as Nigel Harris, maintain that they are often sec tors that would not thrive otherwise, ${ }^{62}$ a view that overlaps with Abrams and Piore's "segmentation" thesis, according to which competition only occurs when migrants settle and leave migrant-only professions. ${ }^{63}$ These ideas are not totally inaccurate: for example, non-immigrants, particularly those with families, find the unsociable hours prevalent in the hospitality sector problematic; whilst new arrivals without families and reduced social networks find them less so. At the same time, the segmentation perspective suffers from two shortcomings. Firstly, and most importantly, it legitimizes abnormal labour relations based on super-exploitation. Secondly, it is mistaken to think that there are no sectors where in the absence of new labour sources, wages and conditions would not be encouraged to rise to attract wage earners. ${ }^{64}$ Some employment sectors could have increased fixed capital investments and thus reduced labour requirements, and others could have relocated production abroad. However, it is unlikely that these are viable options for the sectors employing most migrant labour-all of which are low capital intensive and geographically limited.

A second issue is whether migrants be deemed responsible for the expansion of fixed-term contracts in Spain (or to use the commonly used Castilian term precariedad). Here historical and economic evidence implies otherwise. Precarious conditions were widespread among the Spanish workforce many years before large-scale immigration started in Spain. Indeed, as a result of controversial "labour reforms" performed by an earlier PSOE government led by Felipe González, by the early 1990s, when migrants were a tiny percentage of the population, approximately 40 per cent of Spanish workers were employed "temporarily" (in practice having a chain of fixed-term contracts for the same post). This is a slightly higher percentage than today. Further, according to $\mathrm{CCOO}$, the proportion of insecure contracts within a profession is above average in many areas employing low or even negligible numbers of migrant workers. Migrant workers are more likely to be on such contracts (65 per cent of all migrant workers in 2004), yet so are other social groups that have entered the workforce more recently, such as young people and women. ${ }^{65}$

In short, there is little evidence of substitution of native workers by foreign workers, and while migrants suffer disproportionately from precariedad, they can in no way be held responsible for its extension among Spanish workers.

A theoretical justification for the "reserve army of labour" thesis offered by Martínez Veiga is (citing the words of Borjas) the "law of supply and demand" whereby "an increase in the relative amount of people with a certain qualification is going to reduce their relative wages." 66 However, Martínez Veiga acknowledges that often qualifications are "fictitious" as migrants are forced, due to discrimination and lack of recognition of qualifications, to accept jobs below their true level of qualification, leading to an artificial concentration of migrant workers at the lower end of the job market. Opposing such discrimination is something that can and should be tackled within a No Borders strategy. Another inadequacy with Martínez Veiga's application of Marx's concept is that it overstates the extent to which wages are determined through labour supply and demand, and downplays the role that union activity can play in defending and improving wages and conditions.

\section{Construction}

In 2007 Miguel Pajares investigated the effects of migration on labour by studying the evolution of wage rates set in the "convenios" (binding wage agreements negotiated between union representatives and employers) in sectors with a high degree of migrant labour. He also compared the evolution of wages in a period with a low level of migration (1996-2000) compared to one with a much higher level (2001-2006). In the construction industry he found that convenio wage rates in the later period increased more than in other sectors (by 24 per cent, between 2000 and 2006, compared to 21.4 per cent across all employment sectors). Furthermore, although the proportion of migrants in the building workforce rose sharply from 5.2 per cent of total in the earlier period, to 19.7 per cent in the later, convenio wage levels rose at the same rate in both! At a glimpse, this would appear to provide good evidence against any negative-effect thesis. Nevertheless, the OPI research directed by Carmen González-Enríquez provides observations that require us to give a more nuanced interpretation. The investigation, based on interviews with national, regional, and local trade union leaders, and focus group studies with different groups of unionized and nonunionized workers, suggested that employers had regularly paid their employees above-convenio rates, often paying the complements "cash-in-hand," but that these were sometimes not demanded by migrant workers. The OPI found that migrant workers "did not know the Spanish regulations or are in an irregular situation," which on occasions led them to accept convenio rates. At the same time, Pajares himself identified an increasing tendency for migrant and other workers to work for subcontracting companies that applied an inferior convenio (from an alternative sector to construction) or no convenio at all; ${ }^{67}$ and the OPI report found that subcontracting coexisted on the same sites as more regulated and stable employment, sometimes giving rise to conflict. ${ }^{68}$ 
Treatment of migrant construction workers as "precarious," as is commonly assumed, may be overstated. In fact one report identifies only half as working under fixed-term contracts (a figure only slightly above the average for all employees in all sectors). ${ }^{69}$ Additionally, the large-scale entry of migrants in the lower ranks of the labour force has led to the promotion of significant numbers of native employees within the industry. ${ }^{70}$ In this (limited) sense native earnings and conditions are likely to have improved! (Nevertheless, it should be noted that this may take place at the expense of better-qualified migrant labour.)

\section{Hospitality}

In hospitality, which includes bars, restaurants, and hotels and which is (officially) the second biggest employer of migrant labour, a similar pattern emerges with regard to the convenios. In the sector, binding wage rates have also increased faster than in general (from 2000 to 2006 this was by 23.5 per cent-mildly lower than in construction and higher than the 21.4 per cent wage increase enjoyed by Spanish workers in general). Again, despite the proportion of migrant workers increasing by over 150 per cent (from 10.1 per cent of total wage earners to 24.5 per cent) from the 1996-2000 period to the 2001-2006 period, pay levels grew at the same rate in both. This suggests no weakening in the legal bargaining power of workplaces organized through union structures. Again some native workers benefited from promotion. ${ }^{71}$ In the restaurants and bar chains of this sector, there was a reported absence of conflict between migrant and native workers. Less information is available about the reality in smaller family businesses where wage earners are less likely to be unionized, and this may mean limits to the applicability of the above analysis. A final observation is that there has also been a (declining) tendency to discriminate against migrants by employing them in posts hidden from the public. $^{72}$

\section{Domestic Service}

Domestic service, which includes housekeeping, child care, and care of the elderly, is a more problematic area in terms of pinpointing effects on wages. While we know that in "home help" services, which are often managed by local authorities, convenios are respected and there is little illegal hiring, in the more traditional domestic service, in which domestics are hired individually by employers, there is an absence of convenios, poor regulation, ${ }^{73}$ and very low levels of unionization. ${ }^{74}$ Consequently studies using union sources have little concrete information on the sector. We do know from other research, including Carlota Solé's interviews with migrant domestic workers and a variety of research on Dominican women migrants, that this female-dominated sector has transformed significantly in the last few decades. Previously it centred on the hiring of native Spanish women that had migrated from rural areas, whereas now the vast majority of domestics are migrant. While in 1985 only 7 per cent of domestic workers "lived in," now most do. A further change is that due to the expansion of the domestic service market a great many employers today are "middle-class" families with two wage earners, as opposed to high-income elite families (a shift that could have a depressive effect on wages and conditions due to the generally lower incomes of employers). Large numbers of domestics are undocumented migrant women, ${ }^{75}$ which became visible when a year after the government's 2005 regularization process, the total

Table 1: Evolution of foreign workers in the labour markets employing most migrants

\begin{tabular}{|c|c|c|c|c|c|c|c|}
\hline & $\begin{array}{c}\text { January } \\
2004\end{array}$ & $\begin{array}{c}\text { January } \\
2005\end{array}$ & $\begin{array}{l}\text { growth in } \\
2004(\%)\end{array}$ & $\begin{array}{c}\text { January } \\
2006\end{array}$ & $\begin{array}{l}\text { growth in } \\
2005(\%)\end{array}$ & $\begin{array}{c}\text { January } \\
2007\end{array}$ & $\begin{array}{c}\text { growth in } \\
2006(\%)\end{array}$ \\
\hline construction & 155,108 & 187,097 & (20.6) & 311,281 & (66.3) & 376,732 & (21.0) \\
\hline hospitality & 112,826 & 131,013 & (16.1) & 188,682 & $(44.0)$ & 210,801 & (11.7) \\
\hline $\begin{array}{c}\text { domestic } \\
\text { service }\end{array}$ & 72,361 & 77,098 & (5.2) & 247,874 & (221.5) & 183,174 & $(-26.1)$ \\
\hline $\begin{array}{l}\text { retail and } \\
\text { business }\end{array}$ & 85,433 & 103,350 & (21.0) & 151,098 & (46.2) & 174,494 & (15.5) \\
\hline $\begin{array}{l}\text { other busi- } \\
\text { ness } \\
\text { activities }\end{array}$ & 76,953 & 98,480 & (25.4) & 130,353 & (35.1) & 167,376 & (28.4) \\
\hline agriculture & 120,928 & 113,768 & $(-5.8)$ & 163,290 & (43.5) & 157,912 & $(-3.3)$ \\
\hline
\end{tabular}

Source: from the Labour Statistics Gazette and Secretary of State for Immigration and Emigration, cited in Miguel Pajares,

"Inmigración y mercado de trabajo. Informe 2007. Análisis de datos de España y Catalunya," online: http://www.tt.mtas.es/periodico/ inmigracion/200706/informe.pdf (accessed 9 July 2010.). 
number of domestic employees affiliated to the social security system increased by 221.5 per cent over the previous year (from 77,098 to 247,874 persons). Table 1 shows that this increase had no relation with either the years before or after the process, and little relation with any other employment sector, which would suggest that migrant domestic labour is much more extensive than official figures would imply.

A further relevant finding from research is that domestics often leave behind families and aim to save money to take back to them after a short period or use their job as an entry point to access others in the country. ${ }^{76}$ As a result many change profession after renewing their work permit. ${ }^{77}$

A first crucial issue with regard to domestic employment is that the many accounts dealing with it agree that wages have fallen in this sector. One study, performed by the European Industrial Relations Observatory, calculated that monthly wages of domestics in Spain suffered a sharp drop from $\$ 600-\$ 720$ to $\$ 360$ - $\$ 540$ at the beginning of the decade. ${ }^{78}$ This is a finding which contrasts significantly with those of the other sectors examined.

\section{Summary and Explanations}

Let us summarize our findings thus far: we have shown that in construction and hospitality the incorporation of migrants into the labour force in Spain has responded to the labour shortages that existed before the current crisis. Union agreements do not appear to have been weakened by the large-scale entry of migrant labour in these sectors, However, the tendency towards subcontracting (through which other subsections of workers are employed as well as migrants) and the reduction in informal bonuses due to lack of information has had some negative effects on labour conditions. A counteracting effect is that the working conditions of some non-immigrant employees have improved as they have been promoted to higher grades. In the two industries there is a lack of evidence of significant substitution taking place, at least in the larger unionized workplaces. These discoveries contrast with "common sense" thinking on impacts.

Yet with domestic labour the pattern is different. ${ }^{79}$ Here the transformations in the sector, including the modifications in the social class of employers, have been accompanied by a significant lowering of pay and conditions, and it cannot be ruled out that this acts as a disincentive to nonmigrants seeking occupation in the sector.

The above results indicate that it is at best over-simplistic to claim, as do the major unions, that immigration is favoured by the government and employers because it weakens employment security and pay. ${ }^{80}$ Rather, as Toby Shelley contends, "Within an overall context of filling vacancies and doing so inexpensively, the precise reasons for turning to migrant labour vary from sector to sector and from segment to segment within sectors." 81 It is also highly questionable to maintain, as Martínez Veiga does (again adapting ideas from Borjas), "that immigration redistributes wealth from labour to capital." 82

Lastly, the comparison with the "reserve army of labour" theory, which originally Marx used to describe the urban unemployed that had migrated from the English countryside to the cities (thus "competing" with the new industrial proletariat for jobs), is of questionable use, bearing in mind that migrants generally did not enter Spain until jobs became available and would thus have had little leverage effect on the native employed. The idea that migrants are the source of precarious employment is historically flawed.

Our findings so far echo those of the international literature on effects, which while divergent cluster around "little" or "no" impact, even in the case of intense migration processes. According to calculations by George Borjas in the early 1990s using a range of US research, an increase in migration of 10 per cent would affect wages by between 0.02 per cent and 0.03 per cent-a negligible amount. Other studies have found that there can be temporary negative effects on unskilled social groups. ${ }^{83}$

At the same time as recognizing that claimed impacts are exaggerated, we can infer from our results that it is incorrect to talk in terms of homogeneous effects of migration on wages and conditions. Instead, effects vary, being mediated through a series of other considerations. Concretely, in the light of the evidence presented on the varying effects on different branches of labour, we can venture that effects vary on a positive and negative continuum according to the following factors:

- the relative prominence of irregular employment (of undocumented workers),

- union organization and influence among the workforce,

- the degree of information migrants have about their rights,

- the degree to which migrants are free from discrimination and to which their real qualifications are recognized.

It can be argued that this provisional list of factors weighs far more heavily on outcomes than any "innate" characteristics of migration, such as (as is sometimes argued) that the newness of migrants makes them more predisposed to accepting worse pay and conditions. ${ }^{84}$

Most crucially we have shown that a high degree of illegality, for example among domestics, is associated with lower wage rates, and even the "possibility" of substitution. This finding confirms Teresa Hayter's observation that one of the few conclusive findings on the economics of migrant 
labour is that negative effects will be greatest under conditions of "illegality." 85

One final point is that although the incorporation of migrant labour in the workplace does not have important downward effects on labour conditions, this does not prevent employers and decision-makers from hoping for otherwise. While a more exhaustive examination of this discrepancy would be desirable, we can tentatively suggest that this may be due to an over-reliance on economic explanations of behaviour (e.g., supply and demand in the labour market) and an underestimation of the capacity of migrant and nonmigrant labour to shape labour outcomes through mobility and industrial action.

\section{Unions and Borders}

In recent years there has been a hardening of attitude towards migration among the leaderships of the main Spanish trade unions. Most notably, the largest federation, CCOO, has, according to the OPI, "evolved" from a position "based on the principles of international solidarity" to one that also advocates "controlled immigration" (reducing entry and illegal employment). This bifurcation means that as well as continuing to give advice on regularization and family regroupment, through its migrant services section, the union federation also calls for an increase in workplace inspections and "reducing irregular immigration." 86

Within this paradigmatic shift, CCOO, alongside the UGT, has recently opposed government job-seeking visa schemes to ease entry into the country, and lobbied successfully with employers' organizations in 2007 for a moratorium on the free circulation of workers from the new EU states of Romania and Bulgaria. ${ }^{87}$ A reported outcome of the latter was that the large Romanian population in the peninsula continued to grow but that new migrants had to work "illegally." 88

It could be argued that the unions' stance has become increasingly schizophrenic: on the one hand acting to increase migrants' rights; on the other, effectively collaborating in their exclusion and criminalization.

My examination offers many examples that show why the unions' current perspective is mistaken, in terms of the effects it will have on both migrant workers and the wider working class. My findings back those analyses that propose a radically different union perspective that treats organizing migrant labour as a priority of the trade-union movement, and seeks to increase membership, representation, and support of migrants, while having as a goal the equalization of wages and conditions between migrant and non-migrant. Toby Shelley, who has developed a bleaker vision regarding the labour-market effects of migration in the British context, poses the issue in similar albeit more negative terms, commenting, "If [migrant workers] are being used to drive down wages and conditions ... that is all the more reason to devote time, effort and solidarity in defending them." 89

There is little concrete data on migrant involvement in union structures, but that which is available demonstrates that participation is very limited. In April 2004 only 3.7 per cent of the membership and 1 per cent of the shop stewards of CCOO were "foreign." According to the OPI report, these figures do not show a lack of interest in joining unions, an idea which they support by highlighting that most immigrants in Spain originate from places with a strong tradition of union organization (e.g., Latin America). They add that in some sectors and subsectors immigrants already represent the largest pool of potential new recruits for the unions. ${ }^{90}$

Some progressive developments have emerged recently from within the major union federations, such as the provision of courses for migrant workers on rights and language skills. ${ }^{91}$ Nevertheless, far more could be done.

Positive examples could be learned from the experiences of other workers' organizations internationally. In Britain, for example, the umbrella Trade Union Congress (TUC) has subsumed its "migrant" strategy into a broader program of tackling vulnerability. TUC representatives judge that this has led unions "to deal with the [temporary-work] agency question and not just the migrant question," as well as "to move the argument off of migration status and deflect the 'us-and-them' comments." Polish-speaking regional organizers have been created, in part through collaboration with the Polish trade-union federation Solidarnosc, and there have been attempts to recruit to British unions in Poland itself! $!^{92}$

There appears to be no reason why these creative initiatives and others could not be applied successfully in the Spanish context, and why the union movement as a whole could not give greater commitment to migrant workers. Indeed smaller radical unions, such as the anarcho-syndicalist CGT, have shown a marked commitment to defending migrant rights-leading several local occupations and demonstrations in favour of regularization under the slogan “ipapeles para todos!" (“documents for everyone!”). ${ }^{93}$

In the early 1960s when Spain industrialized rapidly, millions of people left the countryside (especially in the south of Spain) to work in the factories, building sites, and bars of Madrid, Barcelona, the Basque Country, and the Balearic Isles. In their new surroundings, where in some cases they were labelled "immigrants," ${ }^{4}$ they were subject to complaints for their willingness to work large amounts of overtime at lower wages..$^{95}$ Nonetheless, by the mid-seventies these very groups were playing a leading part in the new union movement against Franco, articulated principally through the then-clandestine and grassroots $\mathrm{CCOO}$ movement. ${ }^{96}$ 
Immigrant workers today in Spain are sometimes treated as being of a different disposition to these past waves of migrants, and are frequently referred to in popular, union, and academic contexts as "passive" or even "docile." Jorge Verstrynge and his co-writers dismissively describe migrants as "submissive labour." 97 These characterizations are contradicted by the recent history of struggle by migrant workers: along with the aforementioned strikes at El Ejido, migrants held 700 church occupations and hunger strikes in 2001, and have led several mass protests against racist attacks and tightening of immigration controls. ${ }^{98} \mathrm{We}$ might add to this that the kind of measures promoted by Verstrynge, G. Sánchez Medero, and R. Sánchez Medero, the union leaderships, and the OPI are precisely those that encourage passivity, by legally "tying the hands" of migrant labour.

\section{Conclusion}

Migrants should not be encouraged just to be the object of trade union and political activity but to be its subject. Only such an approach, combined with active opposition to controls, can prevent migrant employment being instrumentalized to produce "social dumping." This is not an abstract desire: among contract cleaners, a relatively high level of union mobilization coincides with a reported lack of division and undercutting among this mixed (migrant/nonmigrant) workforce. ${ }^{99}$

A final note is that the above conclusion is of greater importance under the current economic crisis, which has been particularly pronounced in Spain. As a result of labour market shrinkage there has been a notable decrease in economic "defences" of migration. Furthermore, there has been a "hardening" in government immigration policy, as exemplified by the introduction in 2008 of the Early Payment of Benefits to Foreigners Program. This "encouraged" jobless migrants to voluntarily return to their countries of origin in exchange for early unemployment benefit payments, and widely has been interpreted as signalling an anti-immigration stance. ${ }^{100}$

There is a consensus in the literature and in political circles that Spain, like other Mediterranean countries, is suffering from substantial demographic decline. In 1999 the fertility rate had fallen to a historic and international low of 1.07 children per woman of fertile age. ${ }^{101}$ This figure has risen slightly since, partly as a response to higher birth rates among immigrant women. One recent calculation is that if no more immigrants enter the country, there will be a million fewer sixteen- to sixty-four-year-olds by the early 2020 s, and that the number of sixteen- to thirty-nine-year-olds shall decrease by a third. ${ }^{102}$ This reality, together with the possibility of deepened crisis and instability in the global
South, shall ensure that migrants shall continue to arrive in Spain. A twin No Borders and migrant-orientated union strategy offers the guarantee that this will benefit all working people.

\section{Notes}

1. In the studies examined these two groups of persons are categorized dichotomously in terms of "migrant"/ "immigrant"/"foreign" versus "native"/"autochthonous"/ "Spanish." Occasionally I have used such terms for the sake of comprehension. However they are social constructs with somewhat problematic hierarchical connotations, and I have preferred to use more neutral categorizations such as "migrant" and "non-migrant."

2. I use both "Spain" and "the Spanish State" to describe the territory studied in this article. The Spanish State, a direct translation of "el Estado Español," is politically preferable, as it reflects that Spanish identity is contested by a great many inhabitants, particularly in the Basque Country, Catalonia, and Galicia. However, in many cases, I have preferred to use "Spain" for the sake of clarity.

3. Carmen González-Enríquez, ed., "Los sindicatos ante la inmigración," Documentos del Observatorio Permanente de la Inmigración, http://extranjeros.mtas.es/es /ObservatorioPermanenteInmigracion/Publicaciones /archivos/Los_sindicatos_ante_la_inmigracion.pdf (accessed 9 July 2010.) The unions in Spain were originally formed in accordance with ideological tendency (as opposed to "trades"), with CCOO (the largest federation) associated with the Spanish Communist Party (PCE), and the UGT (the second largest), with the social-democratic PSOE. Today these ideological divisions are more blurred, particularly in CCOO, in part due to the relative demise of the PCE.

4. Miguel Pajares, "Inmigración y mercado de trabajo. Informe 2007. Análisis de datos de España y Catalunya," online: http://www.tt.mtas.es/periodico/inmigracion/200706/ informe.pdf (accessed 9 July 2010.)

5. Ibid., 21 .

6. Alejandro Bolaños, “Portazo a la Inmigración," El País, 7 January 2009.

7. Twenty-seven per cent as stated by Sònia Parella, and "nearly half" according to Carlota Solé: both in Carlota Solé, ed., Inmigración Comunitaria: ¿Discriminación Inversa? (Barcelona: Anthropos Editorial, 2006), 8, 153.

8. Britons are the biggest group of foreign nationals if those persons that spend "a significant part of the year" in Spain are included in figures; see El País, 28 April 2005, 30.

9. Municipal Register figures, reproduced in El País, 28 April 2005,30

10. Guillermo De la Dehesa, “QQué está aportando la inmigración a la economía?”' El País, 25 June 2007, 15.

11. Bolaños. 
12. Ana López-Sala and Ruth Ferrero-Turrión, "Economic Crisis and Migration Policies in Spain: The Big Dilemma" (paper presented at the conference "New Times? Economic Crisis, Geo-political Transformation and the Emerging Migration Order," Centre on Migration, Policy and Society (COMPAS), University of Oxford, 21 and 22 September 2009).

13. Wayne Cornelius, "Spain: The Uneasy Transition from Labor Exporter to Labor Importer," in Cornelius et al., Controlling Immigration: A Global Perspective (Stanford: Stanford University Press, 2004), 409n.

14. Jorge Verstrynge, Gema Sánchez Medero, and Rubén Sánchez Medero, "El Informe sobre la inmigración en España, Viejo Topo, no. 237 (October 2007): 17.

15. Xavier Rius Sant, El libro de la inmigración en España. Historia, legislación, política y debate social desde el franquismo hasta nuestros días. (Cordoba: Almuzar, 1997): 203. Other cases of violence include in Ceuta in 1995 and Terrassa, Catalonia, in 1999; ibid., 127-129, 167-168.

16. Ubaldo Martínez Veiga, Trabajadores invisibles. Precariedad, rotación y pobreza de la inmigración en España (Madrid: Catarata, 2004), 113.

17. SOS Racismo, El Ejido, Racismo y Explotación Laboral. Informe Anual sobre el Racismo en el Estado español (Barcelona: Icaria, 2001), 105.

18. Fixed-term contracts were partly to respond to the varying employment needs of the business: during harvesting 40,000 labourers would be needed; but the rest of the year, 12,000 (Rius Sant, 201.) One small survey of thirty-five migrant labourers in the region discovered that employees normally changed employer after months or even weeks. This has been linked to employers' avoidance of legal responsibilities due to the use of toxic farming chemicals. See Martínez Veiga, 127.

19. Ibid., 201.

20. Jesús Rodríguez, "Regreso a El Ejido," El País Semanal, 19 October 2008, 64 and 65.

21. Ibid., 202.

22. The "apartheid" comparison has been used frequently in media and NGO analyses on El Ejido.

23. Often the equating of violence against "native"/white women with migrant/black males has been a central part of xenophobic/racist mobilizations, such as recently in Italy against the Roma, and in the southern states of the United States under the Jim Crow laws.

24. Rius Sant, 205. Since the events, injustices have persisted. Moroccan nationals have been sentenced for two years for picketing during 2000; yet nobody has been sentenced for the physical attacks or burning and looting of property. Tensions are reported to remain in the area, and there are still 3,000 migrants lacking basic amenities (Rodríguez, 16.)

25. The MP was Joan Puigcercós (ERC); see Rius Sant, 219-230.

26. In this he outrageously concluded that El Ejido was one of the least racist places in the world! (Ibid., 205.)
27. During an interview with El País; see Rius Sant, 223, 230, and 277.

28. This was also the opinion of the minister of labour, Manuel Pimentel, who resigned from his post, claiming that his government was "pushing [migrants] de facto into illegal routes" See Pimentel, "Inmigración: algunas preguntas y respuestas," El País, 9 March 2002.

29. The Guardian, 29 December 2006.

30. La Vanguardia, 24 May 2007.

31. El País, 25 June 2008.

32. Rius Sant, 184.

33. This was the case of the Guardia Civil authorities in Ceuta and Melilla, reproduced in Cornelius; ibid., 408.

34. According to the Spanish police, 97,791 Ecuadorians flew into Spain in 2001, and only 846 left the country that year! The figures for Colombian citizens that year are similar. See Rius Sant, 247.

35. Ibid., 129, 279. In 2002, for example, 9,756 migrants reached the Canaries, of which 5,473 were transferred to the peninsula; ibid., 280.

36. Wayne Cornelius and Takeyuki Tsuda, "Controlling Immigration: The Limits of Government Intervention," in Cornelius et al., 35 .

37. Cornelius, 399.

38. Ibid., 412.

39. Rius Sant, 117-118.

40. Philip Marfleet, Refugees in a Global Era (Basingstoke: Palgrave Macmillan, 2006), 169.

41. Ibid., 169-170.

42. Homera Rosetti, "Inmigración: el fracaso de la regularización," Viento Sur, no. 81 (July 2005).

43. It was also followed by an extraordinary regularisation process only for Ecuadoreans.

44. Teresa Hayter, Open Borders: The Case against Immigration Controls (London: Pluto Press, 2004), 157.

45. I am grateful to Bridget Anderson for these concepts.

46. De la Dehesa.

47. Hayter, 158.

48. However, since the onset of the crisis and faced with a doubling of unemployment, the liberal defence of migration has shifted away from economic arguments to focus on counteracting declining birth rates, yet anti-immigrant attitudes among even progressive sectors remain commonplace. This suggests that there are other more significant reasons for negative appraisals.

49. Albert Recio, "Migraciones y mercado laboral," Viento Sur, no. 96 (March 2008), 59.

50. Cuadernos de Información Sindical. Inmigración y Mercado de Trabajo. Propuestas para la Ordenación de Flujos Migratorios, included in González-Enríquez, ed., 174.

51. Pajares.

52. Ibid.

53. González-Enríquez, 174. The percentage varies in accordance with employment sector or activity.

54. Recio, 61. 
55. Cornelius argues that official unemployment statistics are "to some extent meaningless," 400. However others, such as Recio, would reject this idea.

56. Cornelius, 402-43.

57. Active Population Survey (EPA) figures; see Pajares.

58. Carlota Solé and Sònia Parella, "La inserción de los inmigrantes en el Mercado de trabajo. El caso español," in $E l$ impacto de la inmigración en la economía y en la sociedad receptora, coord. Carlota Solé (Barcelona: Anthropos Editorial, 2001), 46.

59. Both of these trends have reversed somewhat more recently since the onset of the recent crisis.

60. Solé, 45.

61. El País, 5 September 2008, 11.

62. Nigel Harris, The New Untouchables. Immigration and the New World Worker (London: Penguin, 1995).

63. Martínez Veiga, 42-45.

64. The potential of migrant labour to offset rising wage costs for employers has been advanced by Toby Shelley to explain the employment of migrant labour in the meat-packing industry in South Wales, UK, which is a geographical area of high unemployment; see Toby Shelley, Exploited: Migrant Labour and the New Global Economy (London: Zed Books, 2007), 128.

65. Martínez Veiga, 50, 51, 53, 56.

66. Martínez Veiga, 161.

67. Pajares, 139.

68. González-Enríquez, 91-95.

69. Bolaños.

70. Pajares,141-142.

71. Ibid.

72. González-Enríquez, 97-98.

73. Regulation is through a 1985 Royal Decree, which because it permits additional "presence time" to the nine-hour working day, means that many women work a twelve-hour day; see Martínez Veiga, 145, 158.

74. In the whole of Spain CCOO has 1,500 members in traditional domestic service; see González-Enríquez, 98.)

75. Martínez Veiga, 145-159; Solé, 39-42.

76. Solé, 42 .

77. González-Enríquez, 98.

78. Cited in Shelley, 100.

79. Here Pajares's otherwise valuable study makes the mistake of treating this as an exception to the general rule, which seems misplaced if we take into account our observations about the real size of the domestic labour market including irregular employment.

80. González-Enríquez, 98.

81. Shelley, 126.

82. Martínez Veiga, 165.

83. Harris, 194-202; Pajares, 93-98.

84. Indeed it is necessary to ask whether it is the newer migrant, separated from her family, that has the greatest need to increase her earnings in order to be promptly reunited with them.
85. Hayter, 158-159.

86. González-Enríquez, 90-92.

87. Ibid., 92-94.

88. According to the president of the Federation of Romanian Associations in Spain (Federom), in Bolaños.

89. Shelley, 158

90. González-Enríquez, 101-104.

91. Ibid., 100.

92. Jane Hardy and Ian Fitzgerald, "Cross Border Trade Union Collaboration in the Context of Competition and Arbitraging Labour in an Enlarged Europe" (paper presented at ESRC Research Seminar Series "Changing Cultures of Competitiveness," 2008): 16-19. There have also been more divisive union strategies among the British trade unions, as witnessed in the "British Jobs for British Workers" protests organized by the Unite union in JanuaryFebruary of 2009.

93. Rius Sant, 243-244, 261-262, 275.

94. This was the case in the Basque Country and Catalonia where there is a strong nationalist identity and non-Basques and non-Catalans were often treated as "foreigners."

95. Rius Sant, 19.

96. Sebastian Balfour provides a good account of migrant involvement in Barcelona's labour movement in Dictatorship, The City and the Workers. Labour in Greater Barcelona since 1939 (Oxford: Clarendon Press, 1989).

97. Verstrynge, G. Sánchez Medero, and R. Sánchez Medero.

98. Rius Sant, 109, 121, 243-244.

99. González-Enríquez, 98-99.

100. The fact that (in the early stages of the program) only 5 per cent of those eligible opted to take part in the program begs the question whether this was more of a symbolic attempt to have migrants linked with unemployment than a genuine policy to minimize the impact of the crisis. Figure from López-Sala and Ferrero-Turrión.

101.El Mundo, online: www.elmundo.es/2000/03/26/sociedad /26N0090.html (accessed 31 January 2009.)

102. Josep Oliver Alonso, "Elecciones e inmigración," Cinco Días, 13 February 2008.

Luke Stobart has been an activist in Spain and Britain since the mid-nineties. He is also a writer and co-coordinated the books Mundo, S.A. Voces contra la globalización ("On 'Globalisation' and the Global Justice Movement") and Resistencias a la Guerra Global ("On Opposition to the 'War on Terror'”), both published in Spain by Ediciones de la Tempestad. The author thanks Gareth Dale, Miguel Pajares, Philip Marfleet, Bridget Anderson, David Styan, Jane Hardy, Brian Anglo, and Monica Nadal for their ideas and comments, provided through correspondence and meetings, on the topic discussed here. It goes without saying that they do not necessarily share all of the views expressed. 